\title{
COLUMN LEACHING HEAVY METAL FROM TAILINGS FOLLOWING SIMULATED CLIMATE CHANGE IN THE ARCTIC AREA OF NORWAY
}

\author{
SHUAI FU ${ }^{1,2} \&$ JINMEI LU ${ }^{1}$ \\ ${ }^{1}$ Department of Engineering and Safety, UiT The Arctic University of Norway, Norway \\ ${ }^{2}$ Key Laboratory of Poyang Lake Environment and Resource Utilization, Ministry of Education, \\ School of Resources Environmental \& Chemical Engineering, Nanchang University, China
}

\section{ABSTRACT}

This study aimed to assess how the current climate change perspective, with various air temperature $\left(4^{\circ} \mathrm{C}, 10^{\circ} \mathrm{C}, 14^{\circ} \mathrm{C}\right.$ and $\left.18^{\circ} \mathrm{C}\right)$ affected metal releasing from tailings. Heavy metals pollution from tailings leaching are of increasing concern. Column leaching experiment was conducted for 15 weeks to a series of tailings with $20 \mathrm{~mm} /$ week water leaching four temperature situations. Leachate chemical physics properties and concentrations of $\mathrm{Fe}, \mathrm{Ni}, \mathrm{Mn}$ and $\mathrm{Zn}$ in leachates measured at each cycle. Multivariate statistical approaches to evaluate potential risk variations in leachate quality and identify temperature effect on heavy metals leaching in the Arctic area. Results showed higher temperature encourage oxidation and sulfuration in tailings that promoted heavy metal release from tailings through runoff and erosion. $\mathrm{Ni}, \mathrm{Zn}$ and $\mathrm{Mn}$ have the similar resource from tailings and positive correlation in the leaching activity. The leaching of Fe was closely related to temperature change and affect the leaching of other metals. Temperature, however, increased risk by heavy metal leaching from tailings by temperature change should be caught more attention.

Keywords: leaching, heavy metals, temperature, Arctic.

\section{INTRODUCTION}

Tailings are a dominant component in mining waste and act as source of contaminants, which take serious risk to human health and ecological implications [1]. As tailings surround areas are densely polluted recent years, it has been established that tailings operate as an active edaphic compartment which performs a fundamental role in redistribution of metals to ecosystem. In the context, tailings dam has a significant heavy metals leaching contribution to surround environment. It is extremely important biogeochemical zones with the capability of altering the leachate of materials from tailings. Besides the natural processes such as weathering of tailings, considerable amount of metals generated by solution like acid mine drainage, rainfall leaching, etc. enter into deep soils and groundwater [2].

There are many factors affected heavy metals releasing and transporting [3], [4]. Some affected heavy metals form change and some affected acid mine drainage generation. Heavy metals leaching from tailings and acid mine drainage is produced when sulphide-bearing material is exposed to oxygen and water [5]. Many heavy metals leached from tailings when the acid mine drainage generated. Although this process occurs naturally, mining and climate change can promote acid mine drainage generation and tailings leaching simply through increasing the quantity of sulphide expose and reaction rate. There are many factors influence acid mine drainage generation and heavy metals leaching from tailings, such as temperature, precipitant, $\mathrm{pH}$, salinity, conductivity and so on [6]. The degree of environmental pollution by tailings leaching is dependent on its composition, climate change and biochemical reaction, which in turn way vary depending on the geology of the tailings or sources, and surround environment. Temperature played an important role in heavy metals leaching from tailings, especially in the Arctic area. The Arctic has undergone dramatic change during the past decade. And temperature changed twice or more hence than the inland area. Which led 
difference of tailings oxidation and sulfuration between Arctic area and inland. High temperature will accelerated oxidization and sulfidation of tailings, which promote acid mine drainage generation and enhance heavy metals release [7]-[10].

Treatment of tailings leachate which is composed of several dissolved toxic metals is too complex and expensive. If tailings leachate is not managed properly, it causes considerable environmental degradation, water and soil contamination, severe health impact on nearby communities, biodiversity loss and aquatic ecosystem [11].

The aim of this study is to identify leaching characteristics of heavy metals from tailings at different temperature in Arctic area. Knowing contribution of different temperature to heavy metals leaching, the employment of multivariate statistical techniques is benefit for studying their relationships. Which is good for establishing proper management strategies and a decision support system based on risk assessment criteria for improving the sustainability and safety of tailings leaching activities.

\section{MATERIALS AND METHODS}

\subsection{Characteristic of study area}

There is no active mining of massive sulphide deposits in Norway today; but the operations have left behind tailings, waste rocks and adits that in many cases discharge low-pH, metalladen waste streams. As an important mining area in northern Norway and serious tailings deposit by open pit and underground mine, Ballangen faced the risk of metal release from tailings [12]. 7 million tons of tailings deposited in Ballangen, covering an area of $500,000 \mathrm{~m}^{2}$ [13]. A large landfill was located in the coastal zone and is built with pond walls. The deposit took place in the years 1988-2002. A total of 8,537,468 tons of nickel ore was collected with an average content of $0.52 \%$ nickel. On top of the masses is a thin layer of soil, approx. $20 \mathrm{~cm}$. This layer is too thin to prevent air and water from coming into contact with the exhaust masses. Many heavy metals such as iron, copper, zinc, cadmium and nickel had a high content in the tailings and surround soil and water. All surface drainage from the mining area flows into the fjord, surround was noticeably affected by pollution from the mining area, and mainly affected by the heavy metals. It is also worth mentioning that residents in the surround, drinking water source until 2007, have been affected by cancer to a significantly greater extent than the national average. The average temperature for Ballangen municipality was used in the assessment to determine the temperature the samples should be stored in. The temperature is between $-12^{\circ} \mathrm{C}$ and $17.1^{\circ} \mathrm{C}$. In laboratory experiments, leaching activity can't occur when the temperature below $0^{\circ} \mathrm{C}$. Therefore, temperature range $5-18^{\circ} \mathrm{C}$ was chosen in this experiment. Highest temperature was chosen as $18^{\circ} \mathrm{C}$, as the average temperature is expected to increase in the future as a consequence of climate change. The mean annual temperature and precipitation of Ballangen were $4.1^{\circ} \mathrm{C}$ and $1420 \mathrm{~mm}$ in 2016 (Ballangen metreological station located at $68^{\circ} 25^{\prime} 20^{\prime} \mathrm{N}, 17^{\circ} 27^{\prime} 28^{\prime} \mathrm{E}$, eklima.met.no).

\subsection{Experiment and chemical analysis}

A column experiment was conducted in the greenhouse to investigate the impacts of temperature change on heavy metals leaching from mine tailings. Four temperature degrees was set in the experiment: 5,10,14 and 18. Each treatment was established with a repetition. 8 columns were filled with mine tailings (Table 1) from Ballangen and then sent to 4 incubators to keep each at steady temperature, $600 \mathrm{ml}$ water $(80 \mathrm{~mm} / \mathrm{month}$ precipitation) were added in each column every two weeks to leach. Leachate collected each two weeks, 
Table 1: Heavy metals content in mine tailings.

\begin{tabular}{ccc}
\hline Elements & Units & Tailings \\
\hline $\mathrm{CaO}$ & \% TS & 3.18 \\
$\mathrm{MgO}$ & \% TS & 27 \\
$\mathrm{SiO}_{4}$ & \% TS & 39.5 \\
$\mathrm{Al}_{2} \mathrm{O}_{3}$ & \% TS & 4.47 \\
$\mathrm{Fe}_{2} \mathrm{O}_{3}$ & $\% \mathrm{TS}$ & 17.3 \\
$\mathrm{MnO}$ & \% TS & 0.165 \\
$\mathrm{Co}$ & $\mathrm{mg} / \mathrm{kg} \mathrm{TS}$ & 38 \\
$\mathrm{Ni}$ & $\mathrm{mg} / \mathrm{kg} \mathrm{TS}$ & 77.8 \\
$\mathrm{Zn}$ & $\mathrm{mg} / \mathrm{kg} \mathrm{TS}$ & 48.6 \\
\hline
\end{tabular}

$\mathrm{pH}, \mathrm{PE}, \mathrm{TDS}$, salinity and conductivity of the leachates were measured at once by HI98193 [14].

In order to determine total concentrations of five heavy metals ( $\mathrm{Fe}, \mathrm{Zn}, \mathrm{Ni}$ and $\mathrm{Mn}$ ), tailings samples were subjected to microwave-assisted digestion with concentrated $\mathrm{HNO}_{3}$ according to ASTM 3682. Reference materials (CRMs) (GSS-16) as a control sample added in the digestion experiment was in the certified. Leachate was treated follow EPA 200.8. Heavy metals of leachate and tailings were determined by an inductively coupled plasma atomic emission spectrometry (ICP-AES).

\subsection{Statistical analysis}

Basic statistics of the raw data was carried out by SPSS24.0 software. Correlated analysis were applied to the data set for identifying associations (common origin) between metals.

\section{RESULTS AND DISCUSSION}

\subsection{Heavy metals in tailings}

In Table 1, the concentrations of heavy metals of tailings in the study area are shown. $\mathrm{CaO}$, $\mathrm{MgO}, \mathrm{SiO}_{4}, \mathrm{Al}_{2} \mathrm{O}_{3}, \mathrm{Fe}_{2} \mathrm{O}_{3}$ accounted $91.45 \%$ of the tailings (Table 1), suggesting a major of tailings dominated by heavy metals oxide. Sulphur showed low in the tailings and there were less sulphide metals. $\mathrm{SiO}_{4}(39.5 \%)$ was the highest content in the tailings, and the content of Cao (3.18\%) and $\mathrm{MgO}(27 \%)$ in the original tailings were high, they were easy to create buffer solution to retard acid mine drainage generation. High content of $\mathrm{CaO}$ and $\mathrm{MgO}$ is easy to form a solid shell to prevent heavy metals leaching. According to the test, $\mathrm{Co}, \mathrm{Ni}, \mathrm{Mn}$ and $\mathrm{Zn}$ had a high content in the tailings and all of them far exceeds the background of Norway [15]. Although, $\mathrm{Zn}$ and $\mathrm{Mn}$ are essential element of the organism, a too high concentration level can also produce poisoning effect on the human body. Therefore, the total amount of heavy metals in the tailings carried a risk to the surround environment.

The tailings used for the column leaching experiment under different scenarios of climate change showed high total concentrations of metals(Table 1). These concentrations were much higher than those of Norway soils background [15], [16], and with high content of metal oxidize by exposing to air for a long time [17]. It is evident that intense redox reaction occur in the tailings deposite [18].

Heavy metals will be activated by oxidized reaction in tailings, and the chemical forms of heavy metals will be changed [11]. Tailings oxidized is benefit for generating acid mine 
drainage and heavy metals releasing. Couple with precipitant, many heavy metals will be leached from tailings to surround environment.

Many factor will affect the tailings oxidizing, such as temperature, oxygen and precipitation. So, climate change will influence heavy metal storing and transporting in the tailings. Surface water and precipitation will scour and leach tailings, that will accelerate heavy metals release and transport from tailings [19], it take much oxygen to the tailings accelerate the reaction of tailings oxidized. Temperature will promote or restrain oxidized reaction to change heavy metals' form, so as to change their store forms and transport ability [20]. The ability of heavy metals leaching from tailings various from temperature, heavy metals and forms [7].

\subsection{Characterisation of the leachate}

The variation of leachate's physicochemical property presented in Fig. 1. The influence of temperature and time on leachates' $\mathrm{pH}$, TDS, salinity and $\mathrm{SO}_{4}{ }^{2-}$ was studied using column leaching experiment at 5,10,14 and $18^{\circ} \mathrm{C}$. In Fig. 1(a), it is evident that leachates' $\mathrm{pH}$ decreased with temperature rising and leaching cycle on. The highest values of $\mathrm{pH}$ showed at $5^{\circ} \mathrm{C}$ above 7 , and lowest showed at $18^{\circ} \mathrm{C}$, there was little change between $10^{\circ} \mathrm{C}$ and $14^{\circ} \mathrm{C}$, it was even down to 4 when the temperature climb up to $18^{\circ} \mathrm{C}$. Leachates' $\mathrm{pH}$ at $10^{\circ} \mathrm{C}$ were lower than that at $14^{\circ} \mathrm{C}$ from first week to the 12 th week, and opposite showed from 14 th to 20th week. The results from leaching experiment indicated that TDS and salinity changed with the same trend. Both TDS and salinity had high values at the first leaching week, descend to a low value from 1 st week to 5 th week. From 5 th to 15 th week, they kept at this value with little variance. There was little change among the values of TDS and salinity at $10^{\circ} \mathrm{C}$ and $14^{\circ} \mathrm{C}$, and their values of $18^{\circ} \mathrm{C}$ were apparently higher than that at $5^{\circ} \mathrm{C}$. Metallic oxide takes up $91.45 \%$ of the tailings composition. Many metal oxide react with the leaching water, $\mathrm{Mg}^{2+}, \mathrm{Na}^{+}$and $\mathrm{Ca}^{2+}$ dissolved to the water, which increased the values of salinity and TDS of the leachate. Although there was little metallic sulphide in the tailings, $\mathrm{H}^{+}$and $\mathrm{SO}_{4}{ }^{2-}$ generated with metallic sulphide and oxide hydrolysis at the same time. So $\mathrm{pH}$ values of the leachate were lower and $\mathrm{SO}_{4}{ }^{2-}$ contents were higher at the beginning of the leaching cycle. Higher temperature is benefit for tailings sulfuration and oxidation [11], which accelerated acid generation in the mine tailings leaching, so highest and lowest $\mathrm{pH}$ showed in $5^{\circ} \mathrm{C}$ and $18^{\circ} \mathrm{C}$, respectively.

The results of leaching concentrations of leachates from tailings columns as shown in Fig. 2. The highest and lowest leaching concentration of $\mathrm{Fe}$ was at $18^{\circ} \mathrm{C}$ and $5^{\circ} \mathrm{C}$, respectively. There are much difference between leaching character Fe and the other measured heavy metals. Fe keep a low leaching concentration at $5^{\circ} \mathrm{C}$ with small change. Leaching concentration of Fe increased with leaching cycle on at 10 and $14^{\circ} \mathrm{C}$, and higher showed at $10^{\circ} \mathrm{C}$

Both the leaching concentration of $\mathrm{Zn}$ at $5^{\circ} \mathrm{C}$ and $14^{\circ} \mathrm{C}$ was low during the leaching experiment, they increased with the leaching cycle on, and the leaching concentration at $14^{\circ} \mathrm{C}$ was higher than that at $5^{\circ} \mathrm{C}$. Higher leaching concentration was got $10^{\circ} \mathrm{C}$ and $18^{\circ} \mathrm{C}$, they had a decreasing trend with leaching time. The highest leaching concentration at $10^{\circ} \mathrm{C}$ and $18^{\circ} \mathrm{C}$ got at the first leaching cycle, $7347 \mu \mathrm{g} / \mathrm{L}$ and $7909 \mu \mathrm{g} / \mathrm{L}$, respectively. After the first cycle, the leaching concentration at $10^{\circ} \mathrm{C}$ was higher than that at $18^{\circ} \mathrm{C}$.

Leaching concentration of $\mathrm{Ni}$ decreased with leaching cycle on at each test temperature. In each cycle, highest and lowest concentrations were at $18^{\circ} \mathrm{C}$ and $5^{\circ} \mathrm{C}$, the leaching concentration at $10^{\circ} \mathrm{C}$ was higher than that at $14^{\circ} \mathrm{C}$. The highest $\mathrm{Ni}$ leaching concentration is $609 \mathrm{mg} / \mathrm{L}$ and $7 \mathrm{mg} / \mathrm{L}$, at $18^{\circ} \mathrm{C}$ and $5^{\circ} \mathrm{C}$, respectively. 

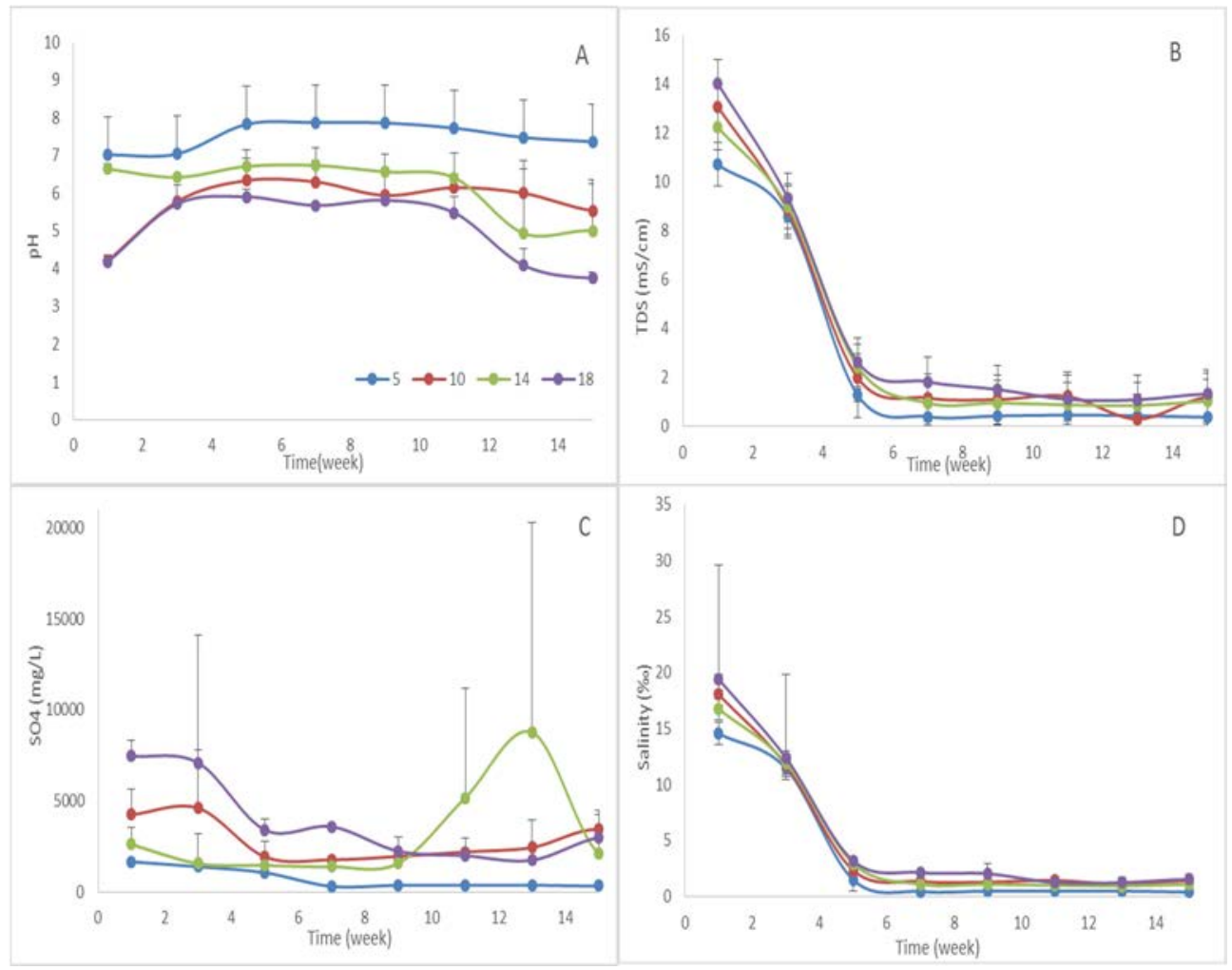

Figure 1: Variations of chemical physics properties of leachates.

At the first cycle, the leaching concentrations of Mn are $574 \mu \mathrm{g} / \mathrm{L}, 2964 \mu \mathrm{g} / \mathrm{L}, 1470 \mu \mathrm{g} / \mathrm{L}$ and $7548 \mu \mathrm{g} / \mathrm{L}$ at $5^{\circ} \mathrm{C}, 10^{\circ} \mathrm{C}, 14^{\circ} \mathrm{C}$ and $18^{\circ} \mathrm{C}$. Leaching concentration of $\mathrm{Mn}$ had a small change from the first cycle to 8 th cycle at $5^{\circ} \mathrm{C}, 10^{\circ} \mathrm{C}$ and $14^{\circ} \mathrm{C}$. At $18^{\circ} \mathrm{C}$, its leaching concentration decreased with leaching time on. In the leaching test, highest and lowest leaching concentration of $\mathrm{Mn}$ were at $18^{\circ} \mathrm{C}$ and $5^{\circ} \mathrm{C}$, and that of $10^{\circ} \mathrm{C}$ was higher than at $14^{\circ} \mathrm{C}$.

From the leaching cycle, all the leaching heavy metals had high and low leaching concentration at $18^{\circ} \mathrm{C}$ and $5^{\circ} \mathrm{C}$, leaching concentration at $10^{\circ} \mathrm{C}$ was higher than that at $14^{\circ} \mathrm{C}$.

There are many heavy metal release kinetic equation in fitting heavy metal leaching from tailings, such as primary diffusion equation, parabolic equation and Elovich equation on heavy metal leaching tailings. All the leaching heavy metals fitted well with the first-order kinetic equation at each temperature. Cumulative concentration increased with leaching cycle on, and the fastest accumulation of the temperature is $10^{\circ} \mathrm{C}$.

\subsection{Effects of temperature on heavy metal leaching from tailings}

The temperature has significant impact on changes in leaching of heavy metals (as shown in Fig. 2). Temperature affect heavy metals leaching from tailings by change metal solubility and biochemical reaction [20]. Lower temperature decreased the metal ions solubility and metal sulphur oxidation reaction, so less heavy metals release to water at $5^{\circ} \mathrm{C}$. Metal oxides 


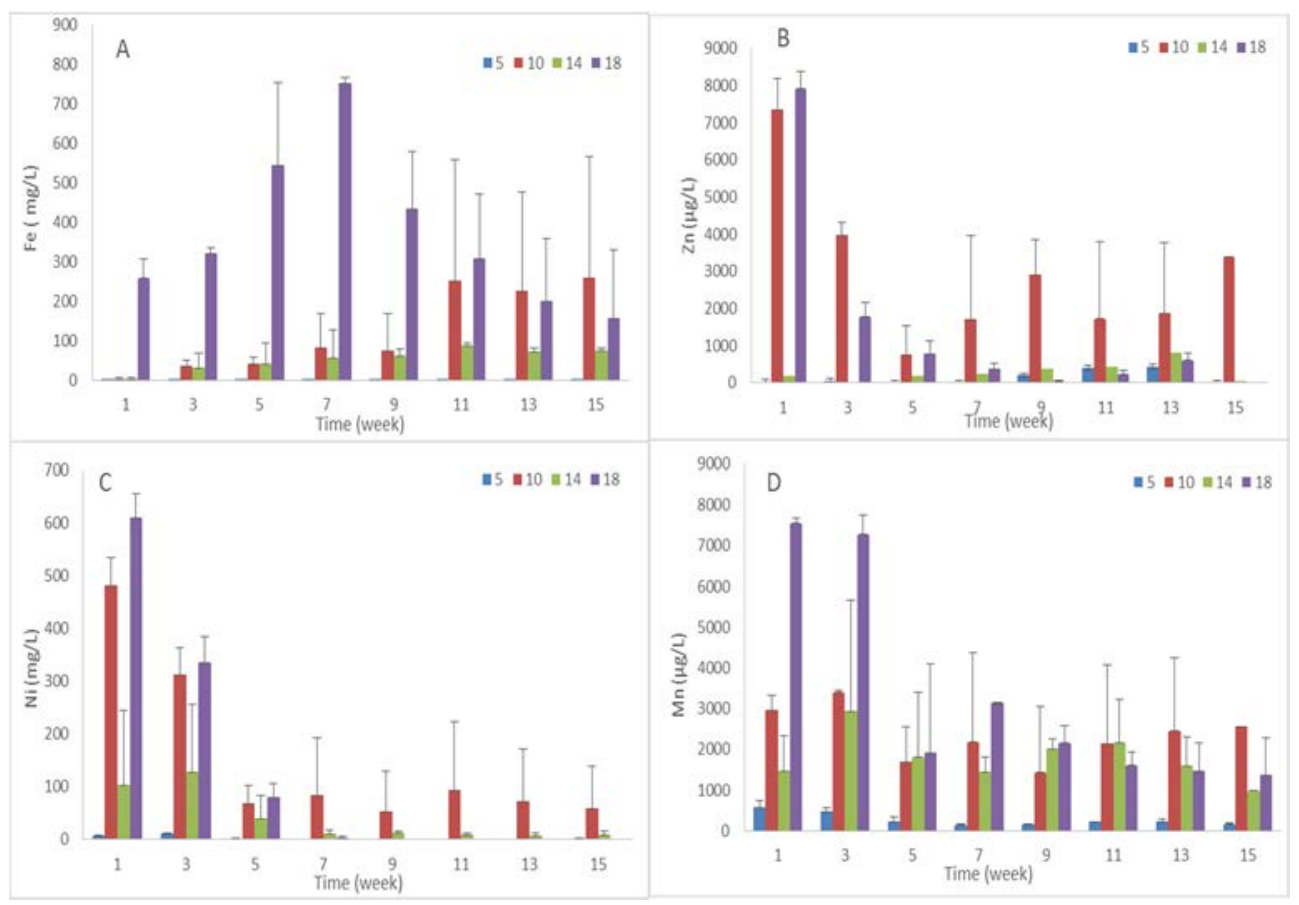

Figure 2: Leached concentrations of $\mathrm{Fe}, \mathrm{Zn}, \mathrm{Ni}$ and $\mathrm{Mn}$ from tailings.

Table 2: Cumulative equation of heavy metals leaching from tailings at different temperatures.

\begin{tabular}{cccc}
\hline $\begin{array}{c}\text { Heavy } \\
\text { metals }\end{array}$ & Temperature & Heavy metals release equation & $\mathrm{R}^{2}$ \\
\hline & 5 & $\mathrm{y}=0.2124 \mathrm{t}+2.6424$ & $\mathrm{R}^{2}=0.6275$ \\
$\mathrm{Fe}$ & 10 & $\mathrm{y}=68.285 \mathrm{t}-209.63$ & $\mathrm{R}^{2}=0.8912$ \\
& 14 & $\mathrm{y}=31.21 \mathrm{t}-63.261$ & $\mathrm{R}^{2}=0.9795$ \\
& 18 & $\mathrm{y}=209.49 \mathrm{t}+146.6$ & $\mathrm{R}^{2}=0.9574$ \\
& 5 & $\mathrm{y}=88.132 \mathrm{t}-292.02$ & $\mathrm{R}^{2}=0.8331$ \\
$\mathrm{Zn}$ & 10 & $\mathrm{y}=1073.5 \mathrm{t}+6834.6$ & $\mathrm{R}^{2}=0.9842$ \\
& 14 & $\mathrm{y}=165.25 \mathrm{t}-329.49$ & $\mathrm{R}^{2}=0.921$ \\
& 18 & $\mathrm{y}=-259.78 \mathrm{t}+11127$ & $\mathrm{R}^{2}=0.8105$ \\
$\mathrm{Ni}$ & 5 & $\mathrm{y}=0.6583 \mathrm{t}+12.906$ & $\mathrm{R}^{2}=0.5193$ \\
& 10 & $\mathrm{y}=46.782 \mathrm{t}+574.11$ & $\mathrm{R}^{2}=0.9162$ \\
& 14 & $\mathrm{y}=12.453 \mathrm{t}+167.61$ & $\mathrm{R}^{2}=0.7101$ \\
$\mathrm{Mn}$ & 18 & $\mathrm{y}=20.196 \mathrm{t}+804.66$ & $\mathrm{R}^{2}=0.4518$ \\
& 10 & $\mathrm{y}=104.64 \mathrm{t}+639,11$ & $\mathrm{R}^{2}=0.9715$ \\
& 14 & $\mathrm{y}=1065.5 \mathrm{t}+2486$ & $\mathrm{R}^{2}=0.9927$ \\
& 18 & $\mathrm{y}=919.76 \mathrm{t}+1274.1$ & $\mathrm{R}^{2}=0.9898$ \\
& & $\mathrm{y}=1228.7 \mathrm{t}+9689.3$ & $\mathrm{R}^{2}=0.9212$ \\
\hline
\end{tabular}


Table 3: Correlations between heavy metals leaching concentrations and chemical physics properties of leachates.

\begin{tabular}{|c|c|c|c|c|c|c|c|c|c|}
\hline & $\mathrm{T}$ & $\mathrm{SO}_{4}$ & $\mathrm{pH}$ & TDS & salinity & $\mathrm{Fe}$ & $\mathrm{Zn}$ & $\mathrm{Ni}$ & $\mathrm{Mn}$ \\
\hline $\mathrm{T}$ & 1 & & & & & & & & \\
\hline $\mathrm{SO}_{4}$ & $0,358^{*}$ & 1 & $*$ & & & & & & \\
\hline $\mathrm{pH}$ & $-0,472^{* *}$ & $-0,408^{*}$ & 1 & & & & & & \\
\hline TDS & 0,052 & 0,206 & $-0,021$ & 1 & & & & & \\
\hline salinity & 0,045 & 0,200 & $-0,026$ & $0,999^{* *}$ & 1 & & & & \\
\hline $\mathrm{Fe}$ & $0,652^{* *}$ & 0,068 & $-0,061$ & $-0,048$ & $-0,053$ & 1 & & & \\
\hline $\mathrm{Zn}$ & 0,127 & 0,097 & $-0,337$ & $0,471^{* *}$ & $0,480^{* *}$ & 0,060 & 1 & & \\
\hline $\mathrm{Ni}$ & 0,219 & 0,179 & $-0,219$ & $0,687^{* *}$ & $0,691^{* *}$ & 0,057 & $0,887^{* *}$ & 1 & \\
\hline $\mathrm{Mn}$ & $0,577^{* *}$ & 0,215 & $-0,288$ & $0,541^{* *}$ & $0,542^{* *}$ & $0,433^{*}$ & $0,638^{* *}$ & $0,802^{* *}$ & 1 \\
\hline
\end{tabular}

and sulphides are easier to oxidize and hydrolyze at higher temperature, and higher temperature will rise water solubility of heavy metals ions, so higher leaching concentration showed at $10^{\circ} \mathrm{C}, 14^{\circ} \mathrm{C}$ and $18^{\circ} \mathrm{C}$. There are significant positively correlation showed at $\mathrm{T}$ (temperature)-Fe and T-Mn, positively correlation showed at T-Ni and T-Zn. It is indicated temperature have positively effect on heavy metals leaching [21]. Because most of Ni was leached out after 6 weeks at $18^{\circ} \mathrm{C}$, so it also had significant positively correlation with temperature. $10^{\circ} \mathrm{C}$ is the proper temperature of heavy metals oxidize and vulcanize in the leaching, more acid generate promoted heavy metals releasing. These results showed that the temperature had appreciable effect on the $\mathrm{Zn}, \mathrm{Ni}$ and $\mathrm{Mn}$ leaching out at $10^{\circ} \mathrm{C}$.

\section{CONCLUSION}

The results definitely demonstrated that temperature change not only resulted in the heavy metal release in tailings but also led to variations of leachate characteristics. In addition to the heavy metal concentrations in tailings, heavy metal leaching was strongly associated with $\mathrm{pH}$, temperature, salinity and TDS. The temperature of the fastest heavy metals accumulation is $10^{\circ} \mathrm{C}$ in the tailings leaching. Proper increase temperature will accelerate tailings oxidization and sulfidization, promote acid generation and increase TDS, finally promote heavy metals releasing.

\section{ACKNOWLEDGEMENT}

This study was financially supported by the MIN-NORTH project funded, Interreg Nord Program: Development, Evaluation and Optimization of Measures to Reduce the Impact on the Environment from Mining Activities in Northern Regions.

\section{REFERENCES}

[1] Azapagic, A., Developing a framework for sustainable development indicators for the mining and minerals industry. Journal of Cleaner Production, 12(6), pp. 639-662, 2004.

[2] Asa, S.C. et al., Application of sequential leaching, risk indices and multivariate statistics to evaluate heavy metal contamination of estuarine sediments: Dhamara Estuary, East Coast of India. Environmental Monitoring and Assessment, 185(8), pp. 6719-6737, 2013. 
[3] Kozak, K. et al., The role of atmospheric precipitation in introducing contaminants to the surface waters of the Fuglebekken catchment, Spitsbergen. Polar Research, 34, 2015.

[4] Dijkstra, J.J., Development of a consistent geochemical modelling approach for leaching and reactive transport prosesses in contaminated materials, 2007.

[5] Akcil, A. \& Koldas, S., Acid Mine Drainage (AMD): causes, treatment and case studies. Journal of Cleaner Production, 14(12), pp. 1139-1145, 2006.

[6] Dijkstra, J.J., Meeussen, J.C. \& Comans, R.N., Leaching of heavy metals from contaminated soils: an experimental and modeling study. Environmental Science \& Technology, 38(16), pp. 4390-4395, 2004.

[7] Visser, A. et al., Climate change impacts on the leaching of a heavy metal contamination in a small lowland catchment. J. Contam. Hydrol., 127(1-4), pp. 4764, 2012.

[8] Tyagi, R., Meunier, N. \& Blais, J., Simultaneous sewage sludge digestion and metal leaching - effect of temperature. Applied Microbiology and Biotechnology, 46(4), pp. 422-431, 1996.

[9] Tsai, L.J. et al., Effect of temperature on removal of heavy metals from contaminated river sediments via bioleaching. Water Research, 37(10), pp. 2449-2457, 2003.

[10] Guo, Y.-G. et al., Leaching of heavy metals from Dexing copper mine tailings pond. Transactions of Nonferrous Metals Society of China, 23(10), pp. 3068-3075, 2013.

[11] Kefeni, K.K., Msagati, T.A. \& Mamba, B.B., Acid mine drainage: Prevention, treatment options, and resource recovery: A review. Journal of Cleaner Production, 2017.

[12] Segalstad, T.V., Walder, I.F. \& Nilssen, S., Mining mitigation in Norway and future improvement possibilities. America Society of Mining and Reclamation (ASMR), 2007.

[13] Iversen, E., Oppfølgende undersøkelser etter nedleggelse av gruvedriften ved Nikkel og Olivin AS, Ballangen kommune. Fysisk/kjemiske undersøkelser i gruveområdet i 2002-2007.

[14] Yan, Q. et al., Leaching experiments of experimental pollution caused by heavy metals of waste rocks in the copper mine: a cause study of Yaoyuanshan Ore deposit in the Fenghuangshan Copper Ore Field, Anhui. China Acta Geoscientica Sinica, 29(2), pp. 247-252, 2008.

[15] Skjelkvåle, B.L. et al., Trace metals in Norwegian surface waters, soils, and lake sediments-relation to atmospheric deposition, 2006.

[16] Skjelkvåle, B. et al., Heavy metal surveys in Nordic lakes harmonised data for regional assessment of critical limits, 1999.

[17] Iversen, E. \& Berge, J., Nikkel og Olivin A/S Utredning av konsekvenser i forbindelse med nytt deponi på Fornes, 2001.

[18] Xiaojuan, S., Shulan, Z. \& Lian, D., Leaching characteristics of MSW compost heavy metals in soil under different temperatures and simulated acid rain. Chinese Journal of Enviromental Engineering, 6(3), pp. 995-999, 2012.

[19] Duo, M., Leaching characteristics and releasing amount evalution of Mo tailing. Liaoning Institute of Technology, 2007.

[20] Tao, Y. et al., Precipitation and temperature drive seasonal variation in bioaccumulation of polycyclic aromatic hydrocarbons in the planktonic food webs of a subtropical shallow eutrophic lake in China. Science of the Total Environment, 2017.

[21] Chen, A. et al., Alkaline leaching $\mathrm{Zn}$ and its concomitant metals from refractory hemimorphite zinc oxide ore. Hydrometallurgy, 97(3-4), pp. 228-232, 2009. 